\title{
触 New Disease Reports
}

\section{First report of a 16SrVI group related phytoplasma associated with cucumber phyllody in a greenhouse in Iran}

\author{
S.A. Esmailzadeh Hosseini ${ }^{1}$, M. Salehi ${ }^{2}$, S.M. Mirchenari ${ }^{1}$, D. Tarizeh ${ }^{1}$ and H. Gholampoor ${ }^{1}$
}

${ }^{1}$ Plant Protection Research Department, Yazd Agricultural and Natural Resources Research and Education Centre, AREEO, Yazd, PO Box 89195-3165, Iran; ${ }^{2}$ Plant Protection Research Department, Fars Agricultural and Natural Resources Research and Education Centre, AREEO, Zarghan, Iran

*E-mail: saesmailzadeh@iripp.ir

Received: 03 Jul 2015. Published: 03 Aug 2015. Keywords: Yazd province, 16SrVI phytoplasma

Greenhouse cucumber (Cucumis sativus) is one of the most economically important vegetable crops in Iran. In September 2014, an outbreak of phyllody disease was observed in up to $82 \%$ of greenhouse cucumber in cultivars Keyhan and Negin in Nasr Abad (Taft, Yazd province). Symptoms were characterised by flower virescence, phyllody and sterility (Fig.1) Total DNA was extracted from $0.2 \mathrm{~g}$ of fresh phyllody-affected flowers and from symptomless cucumber plants (Zhang et al., 1998). DNA samples were tested for phytoplasma by direct and nested PCR using the phytoplasma primers P1/P7 (Deng \& Hiruki, 1991; Schneider et al., 1995) followed by R16F2n/R16R2 (Gundersen \& Lee, 1996). Primer pair P1/P7 amplifies an $1800 \mathrm{bp}$ fragment of the phytoplasma ribosomal operon which includes the 16SrRNA gene, the 16S-23S intergenic spacer region (SR) and a portion of the $5^{\prime}$ region of the $23 \mathrm{~S}$ rRNA gene. R16F2n/R16R2 primer pair amplifies about $1250 \mathrm{bp}$ of the phytoplasma 16S rRNA gene. PCR amplicons of $\sim 1.8$ and $\sim 1.25 \mathrm{kbp}$ were obtained from symptom-bearing, but not from symptomless greenhouse cucumber plants.

Seven R16F2nR16R2 amplicons from infected areas in Nasr Abad were directly sequenced. The R16F2n/R16R2 sequences shared $100 \%$ sequence identity. A consensus sequence corresponding to the Saleh Abad (Nasr Abad, Taft, Yazd province) greenhouse cucumber phyllody (SGCP) was deposited in GenBank (Accession No. KR633068). BLAST search showed that the SGCP phytoplasma had the highest sequence identity with those of the 16SrVI ('Candidatus Phytoplasma trifolii') phytoplasma group. Phylogenetic analysis (MEGA software version 6.0) confirmed that the SGCP phytoplasma clustered within the 16SrVI phytoplasma clade (Fig. 2). R16F2n/R16R2 SGCP phytoplasma sequence computer-simulated restriction analysis (Fig.3) with restriction endonucleases AluI, BamHI, BfaI, BstUI, DraI, EcoRI, HaeIII, HhaI, HinfI, HpaI, HpaII, KpnI, Sau3AI, MseI, RsaI, SspI and TaqI using iPhyclassifier (Zhao et. al., 2009) revealed that virtual RFLP patterns of the SGCP phytoplasma differ from those previously recorded $16 \mathrm{SrVI}$ subgroups (A, B, C, D, E, F, H, I). Although the SGCP phytoplasma RFLP profiles were more similar to those of subgroup A (AY390261), it showed a similarity coefficient of 0.93 ; which suggests that the SGCP phytoplasma may represent a new subgroup within the $16 \mathrm{SrVI}$ phytoplasma group. This is the first report of the association of

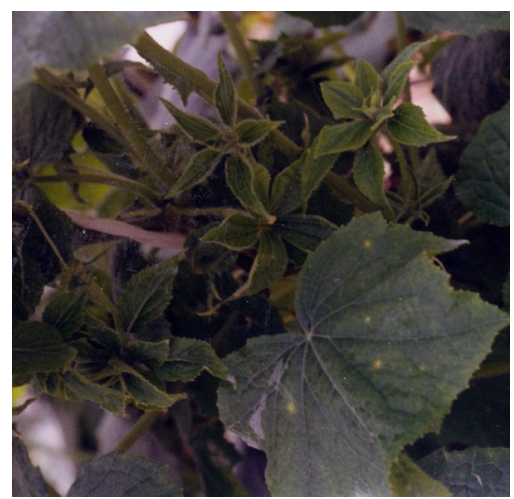



Figure 2 a $16 \mathrm{SrVI}$ phytoplasma with cucumber phyllody disease in a greenhouse in Iran. A 16SrII phytoplasma ('Ca. P. aurantifolia') was associated with cucumber phyllody in a greenhouse of the Fars province (Dehghan et al., 2014). Therefore the SGCP phytoplasma may represent a new epidemiological constraint for the development of the phyllody disease in greenhouses in Iran.

\section{References}

Dehghan H, Salehi M, Khanchezar A, Afshar H, 2014. Biological and molecular characterization of a phytoplasma associated with greenhouse cucumber phyllody in Fars province. Iranian Journal of Plant Pathology 50, 393-401 [in Persian; abstract in English 185-186].

Deng S, Hiruki C, 1991. Amplification of 16 S rRNA genes from culturable and non-culturable mollicutes. Journal of Microbiological Methods 14, 53-61. http://dx.doi.org/10.1016/0167-7012(91)90007-D

Gundersen DE, Lee IM, 1996. Ultrasensitive detection of phytoplasmas by nested-PCR assays using two universal primer sets. Phytopathologia Mediterranea 35, 144-151.

Schneider B, Seemüller E, Smart CD, Kirkpatrick BC, 1995. Phylogenetic classification of plant pathogenic mycoplasma-like organisms or phytoplasmas. In: Razin S, Tully JG, eds. Molecular and Diagnostic Procedures in Mycoplasmology, Vol.1. Academic Press, San Diego, CA, USA, 369-380. http://dx.doi.org/10.1016/B978-012583805-4/50040-6

Zhang YP, Uyemoto JK, Kirkpatrick BC, 1998. A small-scale procedure for extracting nucleic acids from woody plants infected with various phytoplasmas for PCR assay. Journal of Virological Methods 71, 45-50. http://dx.doi.org/10.1016/S0166-0934(97)00190-0

Zhao Y, Wei W, Lee IM, Shao J, Suo X, Davis RE, 2009. Construction of an interactive online phytoplasma classification tool, $i$ PhyClassifier, and its application in analysis of the peach X-disease phytoplasma group (16SrIII). International Journal of Systematic and Evolutionary Microbiology 59, 2582-2593. http://dx.doi.org/10.1099/ijs.0.010249-0

Figure 1

To cite this report: Esmailzadeh Hosseini SA, Salehi M, Mirchenari SM, Tarizeh D, Gholampoor H, 2015. First report of a 16SrVI group related phytoplasma associated with cucumber phyllody in a greenhouse in Iran. New Disease Reports $\mathbf{3 2}, 5$. http://dx.doi.org/10.5197/j.2044-0588.2015.032.005 (C) 2015 The Authors

This report was published on-line at www.ndrs.org.uk where high quality versions of the figures can be found. 